\title{
Investigation of The Effect of Solid Lubricant Particle Sizes on Friction and Wear Properties in Friction Composites: An Experimental Case Study with Graphite
}

\author{
İlker Sugözü ${ }^{1}$ and Banu Sugözü ${ }^{*}$ \\ 0000-0001-8340-8121, 0000-0002-7798-2677 \\ ${ }^{1}$ Mechanical Engineering Department, Faculty of Engineering, Mersin University, Mersin, 33343, Turkey
}

\begin{abstract}
Friction composites consist of many materials with various properties. Solid lubricant is one of these materials. The task of the solid lubricant in the composite is to protect the counter surfaces against wear and to reduce noise and vibration. Typical solid lubricants used in the friction composite are graphite, antimony trisulfide, molybdenum disulfide, copper sulfide, etc. The selection suitable solid lubricants for better braking performance is an important issue, as solid lubricants may decompose at high temperatures, leading to undesirable results. The particle size of the solid lubricant used is at least as important as itself. In this study, the effect of micro and nanoparticle-sized graphite on friction and wear behavior of friction composites was investigated experimentally. Two brake lining were prepared containing $10 \mathrm{wt} . \%$ nanographite and micrographite, were produced by powder metallurgy technique. The brake lining samples have been tested under Friction Assessment and Screening Test (FAST). The frictional and physical properties of the produced samples were determined by appropriate tests. According to the test results obtained, micro and nanoparticle size were compared in many respects and the most ideal size was determined for graphite.
\end{abstract}

Keywords: Graphite, Brake lining, Friction, Wear, Tribology

\author{
Research Article \\ https://doi.org/10.30939/ijastech..928581
}

$\begin{array}{ll}\text { Received } & 27.04 .2021 \\ \text { Revised } & 22.05 .2021 \\ \text { Accepted } & 01.06 .2021\end{array}$

* Corresponding author

Banu Sugözü

banusugozu@mersin.edu.tr

Address: Mechanical Engineering Department, Faculty of Engineering, Mersin University, Mersin, Turkey

Tel: +903122028653

\section{Introduction}

Lining is used to slow down and stop the vehicle. The lining is one of the most important parts of the brake system that wear out and affect the braking performance. Linings are widely used in the automotive industry and other fields. Linings used in automotive brake linings are made of a combination of many materials. The brake lining are multi-component composites containing binder materials, fibers (reinforcement elements), solid lubricants, friction modifiers, abrasives and fillers [1].

When determining friction modifier materials, high friction coefficient and good wear resistance are among the required properties. However, friction materials must maintain a constant coefficient of friction under difficult conditions such as high temperatures. In addition, it is desired to form a good friction pair, not damage the counter material, and exhibit a stable and high friction coefficient under difficult thermal and mechanical effects [2,3]. Today, friction materials that do not threaten human health are being produced [4-7].

Although the tribological properties of asbestos are very good, its use is prohibited due to its negative effects on human health [8].
Solid lubricants reduce the amount of wear of the brake lining by reducing the slip-adhesion effect between the brake lining and the disc as well as helping to remove the produced brake linings from the mold. In addition solid lubricants maintain wear control, noise reduction, and friction stabilization during braking [9]. The solid lubricants such as $\mathrm{Sb}_{2} \mathrm{~S}_{3}, \mathrm{SnS}_{2}, \mathrm{FeS}_{2}, \mathrm{WS}_{2}, \mathrm{MoS}_{2}$ and graphite influence the abundant needs for secure and safe braking performance [10]. Metal sulfides are used as an individual lubricant and also as a lubricant mix in the formulation of friction material [1114]. Among those solid lubricants, graphite (both natural and synthetic) are gradually used in brake lining due to its high anisotropic property, better lubricity at the elevated temperatures [15]. One or more solid lubricants can be used in the lining composition.

Graphite, which has an important place in friction materials, is used in appropriate amounts in the linings and ensures that the friction coefficient distribution remains at the desired level [16]. Graphite is a shiny, soft material composed of layers of carbon atoms arranged in two-dimensional rings. Graphite can be easily machined, resistant to temperature and thermal shock, good heat conductor, resistant to almost all corrosive materials except strong ox- 
idizing agents. A unique feature of graphite is that its strength increases as the temperature increases. It is frequently used in low friction applications. The coefficient of friction between graphite and other materials depends on the counter material, surface roughness, sliding speed, load and environmental conditions.

Cho et al. [17] investigated the effect of three different solid lubricants $\left(\mathrm{Sb}_{2} \mathrm{~S}_{3}\right.$, graphite, and $\left.\mathrm{MoS}_{2}\right)$ on friction characteristics in brake friction materials. For this, they produced three different friction samples containing $10 \%$ graphite by volume, $7 \%$ graphite + $3 \% \mathrm{Sb}_{2} \mathrm{~S}_{3}$ by volume and $7 \%$ graphite $+3 \% \mathrm{MoS}_{2}$ by volume provided that the other materials in the composition are constant. They obtained the tribological properties of friction materials by using a brake dynamometer. As a result, they observed that friction materials containing graphite and $\mathrm{Sb}_{2} \mathrm{~S}_{3}$ improved friction stability and fade resistance.

Kim et al. [18] examined the tribological properties of asbestosorganic brake linings containing graphite and antimony trisulfide $\left(\mathrm{Sb}_{2} \mathrm{~S}_{3}\right)$ in different volume ratios. Using a dynamometer for friction tests, they observed the effects of temperature, sliding speed and applied pressure on the friction coefficient according to the amounts of both solid lubricants. As a result, they reported that the frictional stability of the samples in which both solid lubricants were used was better and the speed sensitivity was lower than the sample containing a solid lubricant. They also emphasized that the lining sample containing high density graphite exhibited better fade resistance during the high temperature friction test than others.

In this study, while the other materials in the lining composition were fixed, two different lining containing $10 \%$ nano and micro graphite by mass were produced and their tribological properties were investigated. It has been observed that the use of nano graphite in the composition has a positive effect on the performance properties of the lining.

\section{Materials and Methods}

Due to the negative effects of asbestos on human health, asbestos-free reinforcement materials are used in the lining content. In determining the material rates during production, the mass ratio is taken as a basis. The powder contents that make up the lining sample are given in Table 1.

Table 1. The composition of the brake lining material specimens.

\begin{tabular}{c|c|c}
\hline \multirow{2}{*}{ Constituent } & \multicolumn{2}{|c}{ Weight percent (\%) } \\
\cline { 2 - 3 } & G10 & NG10 \\
\hline Phenolic resin & 20 & 20 \\
\hline Steel fibre & 8 & 8 \\
\hline Cashew dust & 10 & 10 \\
\hline Brass particles & 5 & 5 \\
\hline Graphite & 10 & 10 \\
\hline Copper particles & 5 & 5 \\
\hline Alumina & 8 & 8 \\
\hline Barite & 34 & 34
\end{tabular}

The graphite ratio of the samples produced was balanced with barite, which is the filling material, and coded as G10 and NG10 according to the amount of nano and micro graphite they contain. The material proportions of the samples are fixed.

Before starting production, the powder materials were weighed with a scale with a sensitivity of $0.001 \mathrm{~g}$. The mixtures prepared in the specified ratios were mixed in the mixer at $120 \mathrm{rpm}$ for 10 minutes to ensure homogeneity. The prepared mixture was transferred to a $25.4 \times 25.4 \mathrm{~mm}$ mold and kept under $8 \mathrm{MPa}$ pressure for 2 minutes and preformed. Then the samples were subjected to hot pressing at $10 \mathrm{MPa}$ pressure and $150{ }^{\circ} \mathrm{C}$ for 10 minutes.

In determining the friction coefficient-time characteristics of the samples, a test set that can transfer the values of the friction coefficient, brake force, hydraulic system pressure, lining surface temperature, which are shown in Fig. 1, to the computer environment during the experiment was used.



Fig. 1. Schematic of brake lining friction test equipment [19]

Load cell was used to measure the friction force between the lining and the brake disc during rotation in the experimental setup. Thus, the rotation force was measured electronically, taking into account the desire of the brake lining to rotate together with the disc due to the friction force arising from the pressure applied to the brake lining during rotation of the disc. There is a speed adjuster in order to use the brake disc in the experimental setup at the desired speed and speed. In order for the experiments to be carried out in accordance with the standards, a non-contact (IR) thermometer that can receive data every second and can operate between 50 and $1000{ }^{\circ} \mathrm{C}$ was placed in the test setup to determine the disc surface temperature. A brake disc made of gray cast iron with a hardness of $116 \mathrm{HB}$ (41.86 HRA) and a diameter of $280 \mathrm{~mm}$ was used in the experiments [19].

The linings produced were placed in the test device with the help of lugs and operated at a speed of $3 \mathrm{~m} / \mathrm{s}$ under $0.7 \mathrm{MPa}$ pressure until $95 \%$ of the sample surface touches the disc surface to ensure that the friction surfaces coincide. The tests were carried out at 1.05 $\mathrm{MPa}$ lining surface pressure and $6 \mathrm{~m} / \mathrm{s}$ speed. The friction coefficient and time values taken during the tests are the arithmetic mean of the values obtained from three samples produced with the same mixture and properties. The friction coefficient for each sample 
was recorded for 700 seconds at 1 second intervals under $1.05 \mathrm{MPa}$ pressure at $6 \mathrm{~m} / \mathrm{s}$.

Considering the force applied to the linings and the friction force obtained from the test device, the friction coefficient was calculated with the formula given in Eq. (1) according to TSE 555 [20].

$$
\mu=\frac{f_{s}}{f_{n}}
$$

In Eq. (1), $f_{s}$ is the friction force and $f_{n}$ is the normal force applied to the brake lining surface and is calculated according to Eq. (2):

$$
f_{n}=P \times A
$$

In Eq. (2), $P$ is the applied pressure (MPa) and $A$ is the friction surface area of the brake lining $\left(\mathrm{mm}^{2}\right)$.

Before and after the friction test, the masses of each sample were determined and the specific wear rate was calculated using the formula given in Eq. (3) according to TSE 555 [20]:

$$
V=\frac{1}{2 \cdot \pi \cdot R} \frac{m_{1}-m_{2}}{n \cdot f_{s} \cdot \rho}
$$

In Eq. (3), $V$ is the specific wear rate $\left(\mathrm{cm}^{3} / \mathrm{Nm}\right), R$ is the distance between the center of the brake lining and the center of the disc (m), $\mathrm{m}_{1}$ and $\mathrm{m}_{2}$ are the mass of the brake lining before and after the test, respectively $(\mathrm{g}), n$ is the total number of turns of the disc during the test, $\rho$ is the density of the brake lining $\left(\mathrm{g} / \mathrm{cm}^{3}\right)$ and $f_{s}$ are the average friction force $(\mathrm{N})$.

The friction stability (\%) of the samples was calculated according to Eq. (4) [21].

$$
F S=\left(\mu_{\text {ort }} / \mu_{\max }\right) \times 100
$$

In Eq. (4), FS is the friction stability (\%) of the sample, $\mu_{\text {ort }}$ is the average friction coefficient, and $\mu_{\max }$ is the maximum friction coefficient value obtained during the test.

A steel ball tip with a diameter of $2.5 \mathrm{~mm}$ was used as the puncture tip in the hardness measurement processes. The applied load is taken as $62.5 \mathrm{kgf}(612.9 \mathrm{~N})$. Hardness measurements were made on the rubbing surface of the samples. Since the dimensions of the samples are $25.4 \times 25.4 \times 9 \mathrm{~mm}$, the values were calculated from the middle and close points of the surface. The arithmetic mean of three sample results with the same content for each sample was taken. The density measurements of the samples were determined in water by Archimedes principle.

\section{Results and Discussion}

Two different composite brake linings containing $10 \%$ by mass of nano and micro graphite were produced, provided that the other materials constituting the lining composition remained constant. As stated in TSE 555, a total of 10 samples were produced by taking into account that the results obtained from 5 test pieces with the same content will be taken into account [20]. The time dependent friction coefficient plots of the samples are shown in Fig. 2 and Fig. 3.

One of the most important features required from brake linings is that the change in the friction coefficient is at a minimum level due to the increase in the interface temperature caused by friction during braking [22-23]. It is preferred that the calculated frictional stability be high. At the same time, the fact that fluctuations are minimal is better in terms of friction performance. [21,24].



Fig. 2. The change of friction coefficient as a function of time for G10 sample

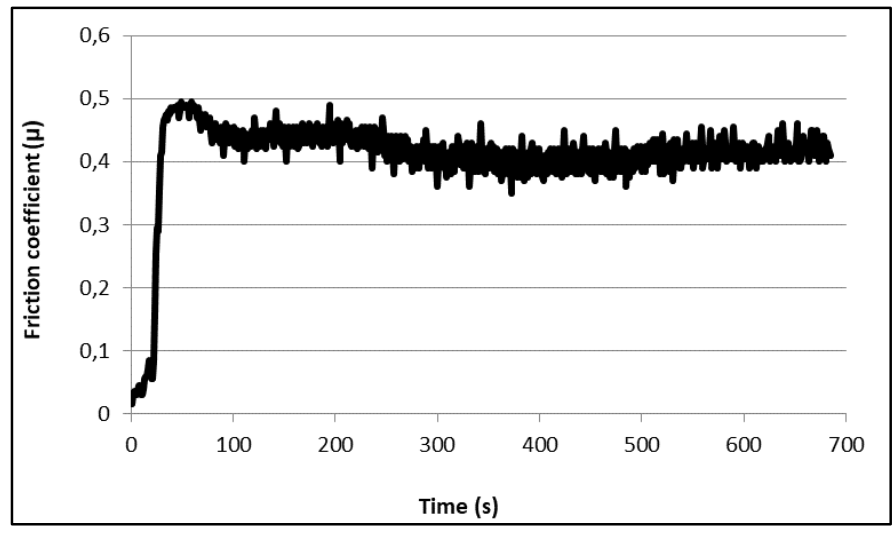

Fig. 3. The change of friction coefficient as a function of time for NG10 sample

When the graphs are examined, the sample with the G10 code containing $10 \%$ micro graphite by mass gave the average lowest friction coefficient value of 0.33 . The NG10 coded sample containing 0.41 and $10 \%$ by mass of nano-graphite gave the average highest friction coefficient value.

Fig. 2 shows the change in the friction coefficient of the NG5 coded sample containing $5 \%$ nano-graphite by mass with respect to time. The temperature at the interface between the lining and the disc is $25^{\circ} \mathrm{C}$ minimum and $121^{\circ} \mathrm{C}$ maximum. The average friction coefficient value is 0.33 and the friction stability is $78 \%$.

Fig. 3 shows the friction coefficient variation of the NG10 coded 
sample containing $10 \%$ nano-graphite by mass depending on time. The temperature occurring between the lining and the disc interface is $45^{\circ} \mathrm{C}$ minimum and $136^{\circ} \mathrm{C}$ maximum. The average friction coefficient value is 0.41 and the friction stability is $81 \%$.

Ostermeyer [25] stated in his study on the dynamics of the friction coefficient that the friction coefficient will decrease due to the increase in the interface temperature.

When the graphs are examined, there is a continuous fluctuating change in the form of a slight decrease in the friction coefficient. Anderson [26] stated that this was due to the periodic continual variation of temperature into the contact areas on the disc surface during friction. Due to this effect, a continuous change occurs in the friction coefficient. In addition, Stachowiak and Batchelor [27] explain this situation by the coalescence and growth of the roughness on the surface of the friction pairs. In this case, an adhesion and a release state are constantly repeated, causing a continuous increase and decrease in the friction coefficient.

When the friction test results were examined, it was seen that the temperature occurring at the interface between the lining and the disc directly affected the friction stability. High friction stability is required in brake lining materials. Fig. 4 shows the friction stabilities of the samples. The highest friction stability value was seen in the sample containing $10 \%$ nano graphite by mass.

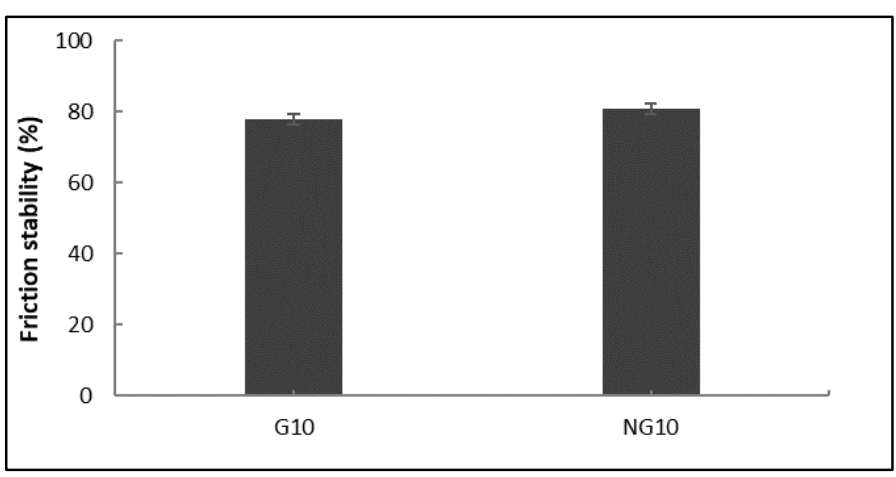

Fig. 4. The friction stabilities of the brake lining samples

The friction and physical properties of samples are given in Table 2. The sample containing $10 \mathrm{wt} \%$ nano graphite (NG10) showed the highest values of $\mu$ ort while the sample containing 10 wt.\% micro graphite (G10) showed the lowest values of $\mu_{\text {ort }}$. According to the studies in the literature, the friction coefficient value is generally greater than 0.1 and smaller than 0.7 . [28].

Table 2. The properties of the brake lining samples.

\begin{tabular}{c|c|c}
\hline Sample & G10 & NG10 \\
\hline Average coefficient of friction $\left(\mu_{\mathrm{ort}}\right)$ & 0.33 & 0.41 \\
\hline Specific wear rate $\left(\mathrm{cm}^{3} / \mathrm{Nm}\right)$ & $2.742 \times 10^{-6}$ & $1.937 \times 10^{-6}$ \\
\hline Brinell hardness $(\mathrm{HB})$ & 43 & 32 \\
\hline Density $\left(\mathrm{g} / \mathrm{cm}^{3}\right)$ & 2.069 & 2.037 \\
\hline
\end{tabular}

It is undesirable for the brake linings to wear very high. Using durable materials to prevent abrasion will cause abrasion of the disc surface [3].
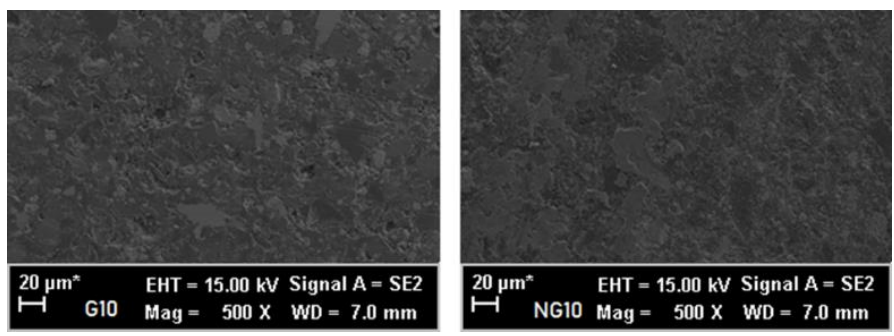

Fig. 5. SEM morphologies of G10 and NG10 coded samples frictional surface.

The microstructure (Scanning Electron Microscope) investigations made on the lining friction surface after the experiment are shown in Fig. 5. When the microstructure images are examined, macro gaps are seen in the lining using micro-sized graphite. It has been determined that there are no gaps in the lining images using nano-sized graphite. In addition, the SEM images show that the friction layer formation is higher in the nano-graphite-containing lining sample. Different materials used in the lining content affect the friction film formation. The friction layer formation depends on the thermal state of the interface during braking. Fibrous materials, organic components and lubricants used in the lining content play an important role in the formation of the transfer layer at the friction interface [29].

\section{Conclusions}

In this study, graphite used as a lubricant in linings was used in nano and micro size. $10 \%$ nano and micro sized graphite is used in the lining. The effect of using nano and micro graphite in lining content on lining performance was evaluated.

- The use of nano graphite has positively affected the friction coefficient of the lining.

- The friction coefficient was stable and high in the lining with nano graphite content.

- The wear rate of the lining containing micro graphite was higher than the lining containing nano graphite.

- Although there was no difference in the density of the linings, the hardness of the lining containing micro graphite was higher.

- It has been observed that the temperature occurring at the interface between the lining and the disc directly affects the friction stability.

- The results obtained from the friction-wear tests are among the values given in literature researches and standards.

\section{Conflict of Interest Statement}

The authors declare that there is no conflict of interest in the study.

\section{CRediT Author Statement}


İlker Sugözü: Conceptualization, Supervision, Writing - original draft,

Banu Sugözü: Writing-original draft, Resources

\section{References}

[1] Sugözü B. Tribological properties of automotive brake pads containing peanut shell powder. Int J Res Eng. 2019;1: 20-24.

[2] Cho KH, Jang H, Hong YS, Kim SJ, Basch RH, Fash JW. The size effect of zircon particles on the friction characteristics of brake lining materials. App Surf Sci. 2008; 258:1862-1868.

[3] Kumar M, Ahlawat V, Sharma V, Kumar M, Singh M. Effect of sliding velocity on wear behaviour and coefficient of friction of walnut shell powder/polyester composites. J Compos Theory. 2019;12: 730739.

[4] Venkatesh S, Murugapoopathiraja K. Scoping review of brake friction material for automotive. Mater Today. 2019;16: 927-933

[5] Jadhav SP, Sawant SH. A review paper: Development of novel friction material for vehicle brake pad application to minimize environmental and health issues. Mater Today. 2019;19:209-212.

[6] Raj JS, Christy TV, Gnanaraj SD, Sugozu B. Influence of calcium sulfate whiskers on the tribological characteristics of automotive brake friction materials. Eng Sci Tech Int J. 2020; 23(2): 445-451.

[7] Jeganmohan SR, Solomon DG, Christy TV. Effect of two different rubbers as secondary binders on the friction and wear characteristics of non-asbestos organic (NAO) brake friction materials. TribologyMaterials, Surfaces \& Interfaces, 2018;12(2): 71-84.

[8] Singaravelu DL, Vijay R, Manoharan S, Kchaou M. Development and performance evaluation of eco-friendly crab shell powder based brake pads for automotive applications. Int J Auto Mech Eng. 2019;16(2): 6502-6523.

[9] Antonyraj IJ, Singaravelu DL. Tribological characterization of various solid lubricants based copper-free brake friction materials-A comprehensive study. Mater Today-Proc, 2020;27: 2650-2656.

[10]Vijay R, Manoharan S, Nagarajan S. Influence of premixed dual metal sulfides on the tribological performance of copper-free brake friction materials. Ind Lubr Tribol. 2021;73(2): 266-274.

[11]Sathickbasha K, Selvakumar AS, Balachandran SR, Hariharasakthisudhan P. Multi-metal sulfide pre-blend combination on the tribological performance of the brake friction material. Ind Lubr Tribol. 2021;73(2):235-334.

[12]Antonyraj J, Vijay R. Influence of WS2/SnS2 on the tribological performance of copper-free brake pads. Ind Lubr Tribol. 2019;71(3): 398-405.

[13]Sathickbasha K, Selvakumar AS, Balaji MS, Rajan BS. The dual role of metal sulfides as lubricant and abrasive: an interface study in friction composite. Mater Res Express. 2019;6(4):045315.

[14]Vijay R, Lenin Singaravelu D, Filip P. Influence of molybdenum disulfide particle size on friction and wear characteristics of non-asbestos-based copper-free brake friction composites. Surf Rev Lett. 2020;27(01):1950085.

[15]Manoharan S, Vijay R, Singaravelu DL, Kchaou M. Experimental investigation on the tribo-thermal properties of brake friction materials containing various forms of graphite: a comparative study. Arab J Sci Eng, 2019;44(2):1459-1473.
[16]Abdel-Rahima1 YM, Darwish SM. Generalized braking characteristics of friction pad synthetic graphite composites. Tribol Int. 2010; 43(4):838-843.

[17]Cho MH, Ju J, Kim SJ, Jang H. Tribological properties of solid lubricants (graphite, $\mathrm{Sb}_{2} \mathrm{~S}_{3}, \mathrm{MoS}_{2}$ ) for automotive brake friction materials. Wear. 2006;260: 855-860.

[18]Kim SJ, Cho MH, Cho KH, Jang H. Complementary effects of solid lubricants in the automotive brake lining. Wear. 2007; 40:15-20.

[19]Sugözü I. Investigation of using rice husk dust and ulexite in automotive brake pads. Mater Test. 2015;57(10): 877-882.

[20]TSE 555. Highway Vehicles-Brake System-Brake Pads for Friction Brake. Turkish Standard Institute. Ankara, Turkey. 1992.

[21]Bijwe J, Aranganathan N, Sharma S, Dureja N, Kumar, R. Nanoabrasives in friction materials-influence on tribological properties. Wear. 2012;296:693-701.

[22]Persson BNJ. Theory of Friction - the Role of Elasticity in Boundary Lubrication. Phys Rev B, 1994;50 (7):4771-4786.

[23]Tabor D. Friction as a dissipated process, Friction of organic polymers in fundamentals of friction. Macroscopic and Microscopik Processes, 1996;3:220.

[24]Sugozu B. Tribological properties of brake friction materials containing fly ash. Ind Lubr Tribol. 2018;70: 902-906.

[25] Ostermeyer GP. On the dynamics of the friction coefficient. Wear. 2003;254: 852-858.

[26]Anderson AE. Friction and Wear of Automotive Brakes, USA, Friction, Lubrication and Wear Technology ASM Handbook. 1992.

[27]Stachowiak GW, Batchelor AW. Adhesion and adhesive wear, In: Engineering Tribology, Eds, A.B.D: Butterworth-Heinemann, 2001;533-553.

[28]Moore DF, Princippless and application tribology, Oxford, Pergamon Press. 1975;109-156.

[29]Jeganmohan S, Sugozu B. Usage of powder pinus brutia cone and colemanite combination in brake friction composites as friction modifier. Mater Today-Proc. 2020; 27:2072-2075. 